\title{
SISTEM PAKAR DIAGNOSA PENYAKIT SALURAN PERNAFASAN DENGAN METODE FUZZY TSUKAMOTO
}

\author{
Dhevi Dadi Kusumaningtyas ${ }^{1)}$; Muhammad Hasbi'); Hendro Wijayanto ${ }^{3)}$ \\ ${ }^{1)}$ Program Studi Sistem Informasi STMIK Sinar Nusantara \\ ${ }^{2,3)}$ Program Studi Teknik Informatika STMIK Sinar Nusantara \\ ${ }^{1)}$ dhevi.dadi@gmail.com; ${ }^{2)}$ mhasbi@sinus.ac.id; ${ }^{3)}$ hendro@sinus.ac.id ${ }^{3}$
}

\begin{abstract}
Respiratory diseases are one of the most common diseases in Indonesia. Respiratory diseases increase the risk of fatal if not treated immediately. However, it is unfortunate that knowledge about the risk of respiratory disease is still lacking. The search method used in making this expert system is forward chaining with binary tree structure. Namely doing the processing of a set of data, then conducted inference in accordance with the rules applied to find the optimal conclusion. Experts provide rules for determining symptoms and illness. While the calculation and ranking of diseases that may suffer patients using the method fuzzy tsukamoto to provide the results of calculations that are certain based on the parameters. Then the patient's diagnostic process is done by the system. The Diagnostic Expert System for Respiratory Disease has been successfully established and can be used to assist in estimating the illness suffered by the patient as the result of the developed system is not much different from the running system. Based on the comparison of disease diagnosis result in expert system with manual system then the system accuracy level is $80 \%$. Based on the website view has the largest percentage of 71.42 in good description, for user friendly / ease of respiratory system experts get the largest percentage of 85.71 in good information, to assist in the process of disease information and treatment get the largest percentage of 57.14 in a good description, to help the diagnosis process becomes easier to get the largest percentage of 71.42 in good information, for this expert system provides information on respiratory disease treatment accurately get the largest percentage of 57.14 in either.
\end{abstract}

Keywords : Expert System, Respiratory Disease, Fuzzy Inference SystemTsukamoto

\section{PENDAHULUAN}

Dalam dunia kedokteran kita menjumpai sesuatu yang bersifat pemikiran-pemikiran yang semi relative. Konsep sistem pakar didasarkan pada asumsi bahwa pengetahuan pakar dapat disimpan dan diaplikasikan ke dalam komputer, kemudian diterapkan oleh orang lain saat dibutuhkan. Dengan mengimplementasikan sistem pakar ke dalam komputer, dapat menghasilkan beberapa manfaat seperti ke akurasian, kecepatan, dan dapat diakses kapan pun sehingga dapat meringankan tugas dari para pakar di bidangnya. Salah satu pemanfaatan sistem pakar adalah dalam bidang kedokteran atau kesehatan. Pengimplementasian sistem pakar pada dunia kedokteran atau kesehatan dapat berupa diagnosa penyakit, konsultasi penjagaan kesehatan sampai pemberian saran penentuan solusi dari hasil diagnosa yang ada [1].

Penyakit saluran pernafasan merupakan salah satu jenis penyakit yang paling banyak di derita oleh masyarakat Indonesia. Penyakit saluran pernafasan bisa meningkatkan risiko fatal apabila tidak segera ditangani. Namun sangat disayangkan bahwa pengetahuan tentang resiko penyakit saluran pernafasan di masyarakat masih sangat kurang. Inilah yang melatarbelakangi pembangunan sistem pakar diagnosa dan penanganan untuk penyakit saluran pernafasan [2]

Metode pencarian yang digunakan dalam pembuatan sistem pakar ini adalah forward chaining dengan struktur binary tree yaitu dengan melakukan pemrosesan berawal dari sekumpulan data untuk kemudian dilakukan inferensi sesuai dengan aturan yang diterapkan hingga ditemukan kesimpulan yang optimal. Pakar memberikan rule-rule atau aturan dalam menentukan gejala dan penyakit. Sedangkan perhitungan dan perangkingan penyakit yang mungkin diderita pasien, menggunakan metode fuzzy tsukamoto untuk memberikan hasil perhitungan yang bersifat pasti berdasarkan dengan parameter yang ada, kemudian proses diagnosa pasien dilakukan oleh sistem. 
Berdasarkan penjabaran sebelumnya, maka penulis membuat sistem pakar dengan judul "SISTEM PAKAR DIAGNOSA PENYAKIT SALURAN PERNAFASAN DENGAN METODE FUZZY TSUKAMOTO" yang berfungsi memudahkan user yang ingin mendiagnosa jenis penyakit saluran pernafasan apa yang di derita, penyebab dan untuk mengetahui informasi tentang penanganan penyakit saluran pernafasan dan untuk mengurangi terjadinya human error yang terkadang ditemui dokter melakukan kesalahan diagnosa selain itu memberikan penanganan yang konsisten, cepat dan akurat kepada pasien.

\section{TINJAUAN PUSTAKA}

\subsection{Logika Fuzzy}

Logika fuzzy dapat dianggap sebagai kotak hitam yang berhubungan antara ruang input menuju ruang output. Kotak hitam yang dimaksudkan adalah metode yang dapat digunakan untuk mengolah data input menjadi output dalam bentuk informasi yang baik [3].

\subsection{Fungsi keanggotaan}

Fungsi keanggotaan (member function) merupakan sebuah kurva yang pemetaannya melalui titik-titik input data ke dalam nilai keanggotaan (derajat keanggotaan) yang di dalamnya terdapat nilai 0 sampai 1 . salah satu cara untuk mendapatkan nilai keanggotaan adalah dengan cara pendekataan fungsi, ada beberapa fungsi untuk menentukan sebuah nilai keanggotaan yaitu linear, kurva segitiga, kurva trapesium dan metode lainnya [4].

\subsection{Fuzzy Inference System Tsukamoto}

(FIS)

Dalam metode Tsukamoto, setiap konsekuensi dari aturan IF-THEN harus diwakili oleh himpunan fuzzy dengan fungsi keanggotaan yang monoton. Akibatnya, output setiap aturan yang tegas disajikan sesuai dengan a-predikat (firestrength). Hasil akhir diperoleh dengan rata-rata tertimbang. Sebagai contoh, ada dua masukan variabel variabel $1(\mathrm{x})$ dan variabel $2(\mathrm{y})$ - dan satu variabel output - variabel $3(\mathrm{z})$. Variabel 1 dibagi menjadi dua set, yaitu $A 1$ dan $A 2$. Variabel 2 adalah dibagi menjadi dua set, yaitu B1 dan B2. Variabel 3 dibagi menjadi dua set, yaitu $\mathrm{C} 1$ dan $\mathrm{C} 2$ (C1 dan $\mathrm{C} 2$ harus monoton). Dua aturan yang digunakan sebagai berikut: [5] [6]

\author{
[R1] IF ( $x$ is A1) AND ( $y$ is B2) THEN ( $z$ is \\ C1) \\ [R2] IF ( $x$ is A2) AND ( $y$ is B2) THEN ( $z$ is \\ C2)
}

\subsection{DFD}

Data Flow Diagram atau dalam bahasa Indonesia menjadi Diagram Alir Data (DAD) adalah representasi grafik yang menggambarkan aliran informasi dan transformasi informasi yang diaplikasikan sebagai data yang mengatur dari masukan (input) dan keluaran (output) [7].

\subsection{ERD (Entity Relationship Diagram)}

Entity Relationship Diagram digunakan untuk menggambarkan struktur Logical database dalam bentuk diagram ERD, serta menyediakan cara yang sederhana dan mudah untuk memahami bagian berbagai komponen dalam desain database [7]

\section{METODE PENELITIAN}

Untuk memperoleh data yang tepat dan akurat guna kesempurnaan sistem yang dibuat, maka digunakan beberapa metode pengumpulan data antara lain:

\subsection{Metode Pengumpulan Data}

Beberapa teknik pengumpulan data. Teknik-teknik tersebut diantaranya :

\section{a. Metode Wawancara}

Dalam metode ini penulis mengadakan tanya jawab kepada seorang. Metode ini bertujuan untuk memperoleh data yang akurat karena pakar/dokter dapat memberikan masukan berdasarkan pada penanganan penyakit yang diderita.

\section{b. Metode Studi Kepustakaan}

Yaitu dengan cara mencari referensi atau teori yang diperlukan melalui buku-buku acuan dan jurnal ilmiah yang ada kaitannya dengan masalah-masalah pembuatan sistem pakar diagnosa penyakit pernafasan.

\section{HASIL DAN PEMBAHASAN}

\subsection{Analisis Tabel Keputusan}

Tabel keputusan digunakan sebagai acuan dalam membuat pohon keputusan dan kaidah yang digunakan. Maka tabel keputusan pada sistem pakar untuk mendeteksi penyakit saluran pernafasan dapat dilihat pada Tabel 1. 
Tabel 1 Tabel Keputusan Sistem Pakar

\begin{tabular}{|c|c|c|c|c|c|c|c|c|c|c|c|c|c|}
\hline \multirow{2}{*}{ 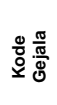 } & \multicolumn{13}{|c|}{ Kode Penyakit } \\
\hline & ఏ̄ & ถั๊ & 浞 & 호 & 놈 & $\stackrel{\circ}{\circ}$ & ิㅗㅁ & $\stackrel{0}{\circ}$ & 8 & 움 & $\frac{F}{2}$ & $\frac{\pi}{2}$ & $\frac{m}{\alpha}$ \\
\hline G01 & $\checkmark$ & $\checkmark$ & & & $\checkmark$ & $\mathrm{v}$ & $\sqrt{ }$ & & $\sqrt{ }$ & & $\sqrt{ }$ & & $\sqrt{2}$ \\
\hline $\begin{array}{ll}\text { G02 } \\
\text { G03 }\end{array}$ & $\frac{7}{v}$ & $\sqrt{ }$ & & & $\sqrt{ }$ & $\frac{1}{2}$ & $\sqrt{ }$ & & $\sqrt{1}$ & & & & \\
\hline G04 & & & & & $\mathrm{v}$ & $v$ & & & - & & 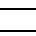 & & 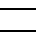 \\
\hline$\frac{G 05}{\text { G06 }}$ & & & $\sqrt{v}$ & $\sqrt{ }$ & & $v$ & & $\sqrt{ }$ & 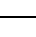 & $\sqrt{ }$ & $\sqrt{ }$ & $\sqrt{2}$ & $\sqrt{ }$ \\
\hline G07 & & $\sqrt{4}$ & & & $\sqrt{ }$ & & $y$ & & $y$ & & 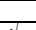 & & \\
\hline $\begin{array}{l}\text { G08 } \\
\text { G09 }\end{array}$ & & $\frac{v}{\sqrt{3}}$ & & & & & $v$ & & $\frac{\mathrm{v}}{\mathrm{y}}$ & & v & & - \\
\hline G10 & & & $\sqrt{v}$ & & & & & & & & - & & \\
\hline$\frac{G 11}{G 12}$ & & & $\sqrt{ }$ & & & & & & $y$ & & $y$ & & 工 \\
\hline G13 & & & v & v & & & 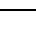 & V & & d & & & d \\
\hline G14 & & & $\sqrt{V}$ & $\sqrt{v}$ & & & & $\sqrt{v}$ & & & 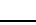 & $\sqrt{2}$ & \\
\hline $\begin{array}{l}\text { G15 } \\
\text { G16 }\end{array}$ & & & & $v$ & & & & $\gamma$ & 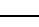 & $\mathrm{v}$ & $y$ & 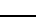 & - \\
\hline G17 & & & & & & & $\sqrt{v}$ & & - & & & & \\
\hline G19 & & & & & & & $\sqrt{7}$ & & $v$ & & & & - \\
\hline G20 & & & & & & & & & & v & $\sqrt{ }$ & $\sqrt{ }$ & 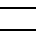 \\
\hline$G_{212}$ & & & & & & & & & & & & $v$ & \\
\hline$\frac{G_{22}}{202}$ & & & & & & & & & & & & $v$ & $y$ \\
\hline G24 & & & & & & & & & & & & & $\sqrt{v}$ \\
\hline G25 & & & & & & & & & & & $y$ & & $\sqrt{2}$ \\
\hline G27 & & & & & & & & & & & 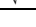 & v & - \\
\hline G28 & & & & & & & & & $\sqrt{ }$ & 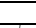 & 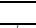 & & \\
\hline G30 & & & & & & & & & & & $\frac{1}{y}$ & & \\
\hline G31 & & & & & & & & & & $\frac{1}{4}$ & & & - \\
\hline
\end{tabular}

\subsection{Analisis Pohon Keputusan}

Pembentukan pohon keputusan pada sistem pakar untuk mendeteksi penyakit saluran pernafasan ini adalah menggunakan binary tree. Berdasarkan analisis metode pelacakan maka pohon keputusan yang digunakan yaitu pohon keputusan forward chaining dapat dilihat pada Gambar 1 dan Gambar 2.

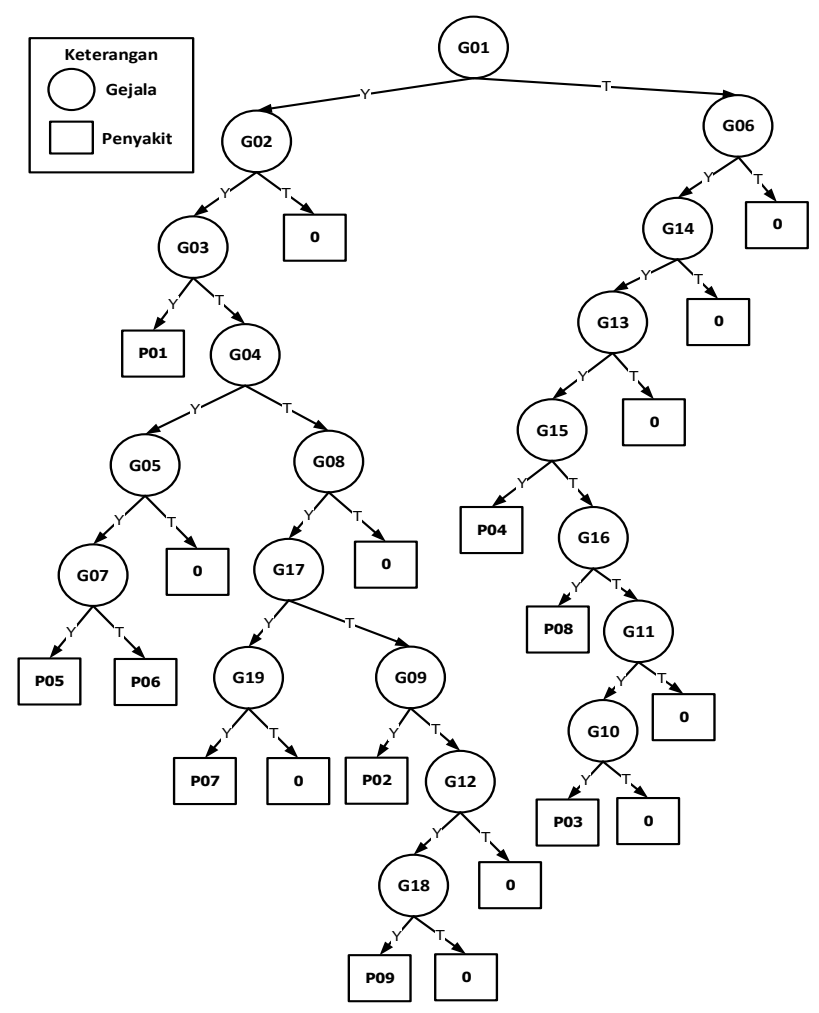

Gambar 1. Binary Tree Forward Chaining

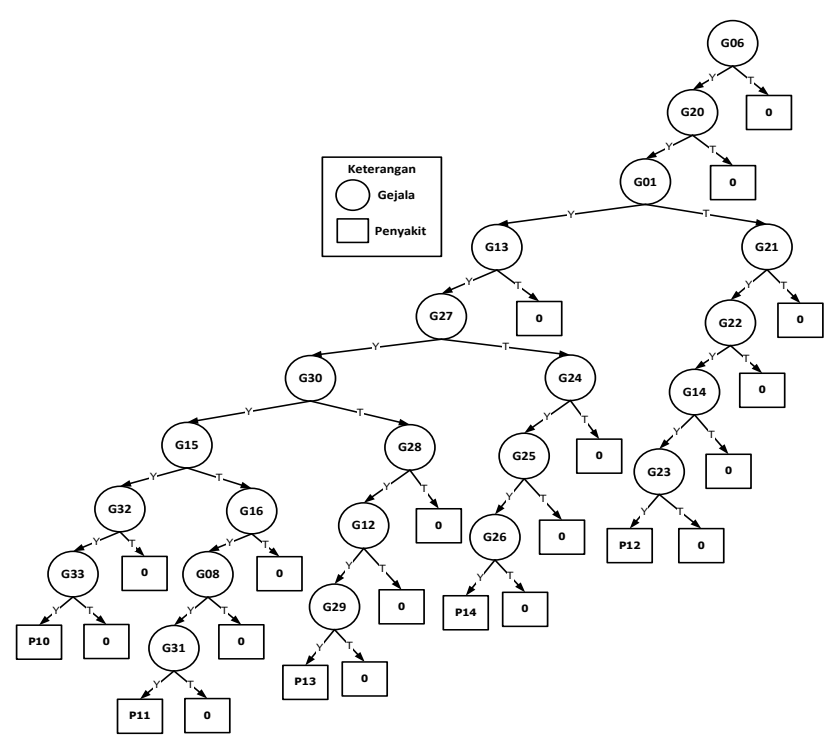

\section{Gambar 2 Binary Tree Forward Chaining (lanjutan)}

\subsection{Analisis Kaidah Penyakit}

Kaidah aturan produksi metode forward chaining dapat dilihat pada Tabel 2.

\section{Tabel 2 Kaidah Aturan Produksi Metode} Forward Chaining

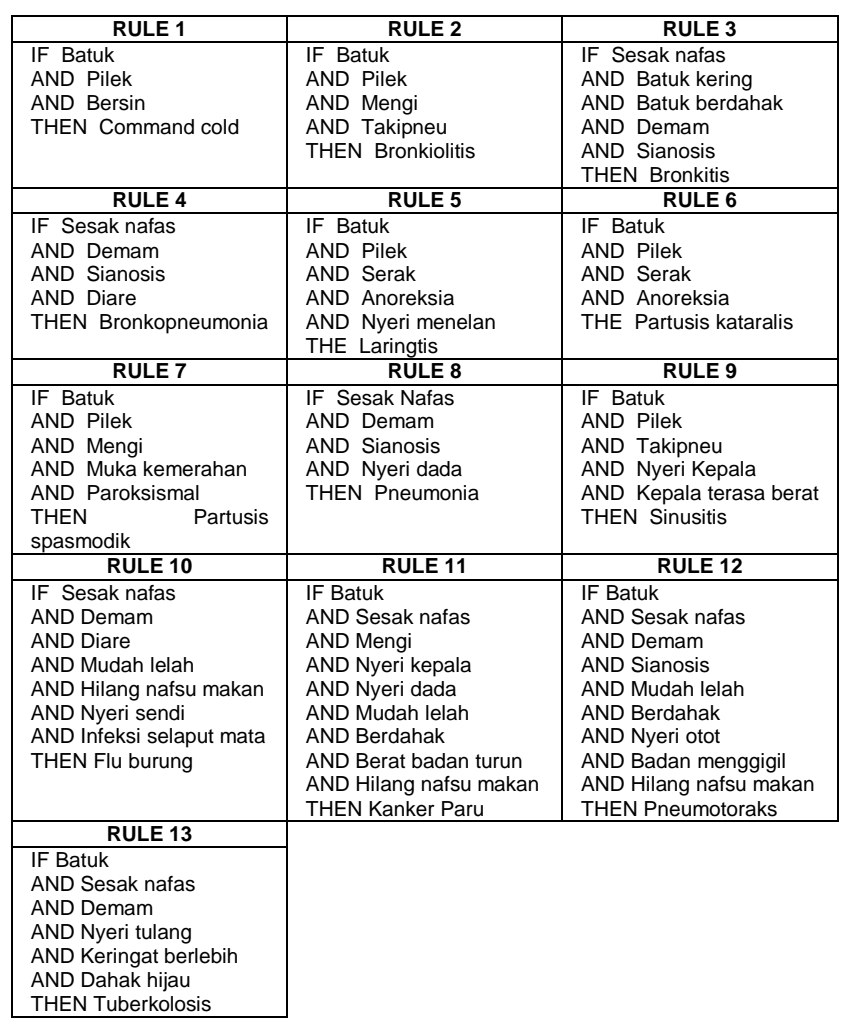

\subsection{Analisis Fungsi Derajat Keanggotaan}

Derajat keanggotaan merupakan hasil perhitungan yang bersifat pasti atau numerik. Berdasarkan batas domain yang telah 
ditentukan penulis maka untuk batas tingkat penyakit dapat dilihat pada Tabel 3.

Tabel 3 Batas Tingkatan Gejala

\begin{tabular}{|c|c|c|}
\hline \multirow{2}{*}{ Tingkatan } & \multicolumn{2}{|c|}{ Batas } \\
\cline { 2 - 3 } & $\min$ & $\max$ \\
\hline Sedikit Mengganggu & 0 & 3 \\
\hline Mengganggu & 4 & 6 \\
\hline Sangat Mengganggu & 7 & 10 \\
\hline
\end{tabular}

Keterangan:

0 = tidak ada rasa sakit. merasa normal.

1 = nyeri hampir tak terasa (sangat ringan).

2 = nyeri ringan.

3 = nyeri sangat terasa (bisa ditoleransi).

4 = kuat, nyeri yang dalam (menyedihkan)

5 = kuat, dalam, nyeri yang menusuk (sangat menyedihkan)

6 = kuat, dalam, nyeri yang menusuk begitu kuat sehingga tampaknya sebagian mempengaruhi sebagian indra.

7 = sama seperti 6 ditambah rasa sakit benar-benar mendominasi indra anda menyebabkan tidak dapat berkomunikasi dengan baik dan tak mampu melakukan perawatan diri.

8 = nyeri begitu kuat sehingga anda tidak lagi dapat berpikir jernih, dan sering mengalami perubahan kepribadian yang parah jika sakit datang dan berlangsung lama.

9 = Nyeri begitu kuat sehingga Anda tidak bisa mentolerirnya dan sampai-sampai menuntut untuk segera menghilangkan rasa sakit apapun caranya.

$10=$ Nyeri begitu kuat tak sadarkan diri.

Dengan rumus tingkatan penyakit saluran pernafasan dengan $\mathrm{G}$ adalah:

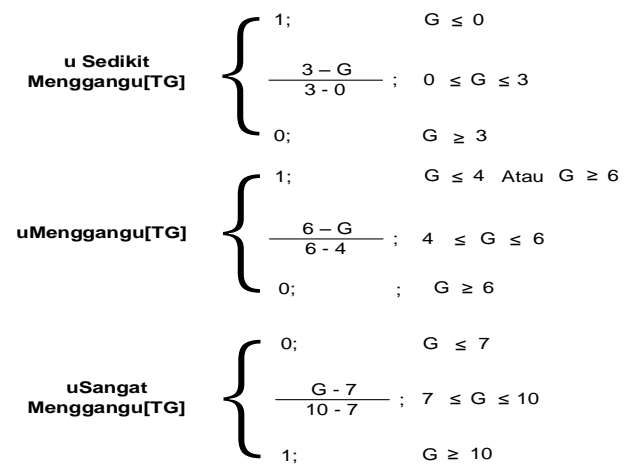

\subsection{Diagram Konteks}

Diagram konteks pada sistem pakar ini dapat dilihat pada Gambar 3.

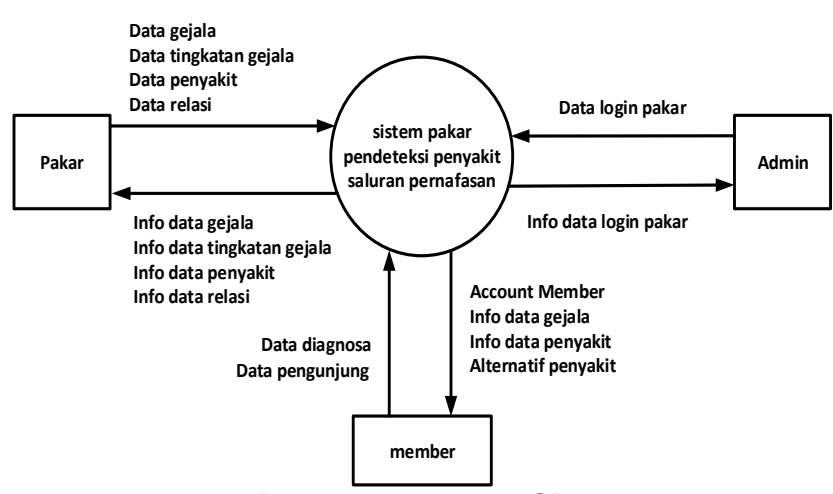

Gambar 3 Diagram Konteks Sistem Pakar

\subsection{Data Flow Diagram (DFD) Level 0}

DFD level 0 pada sistem pakar ini dapat dilihat pada Gambar 4

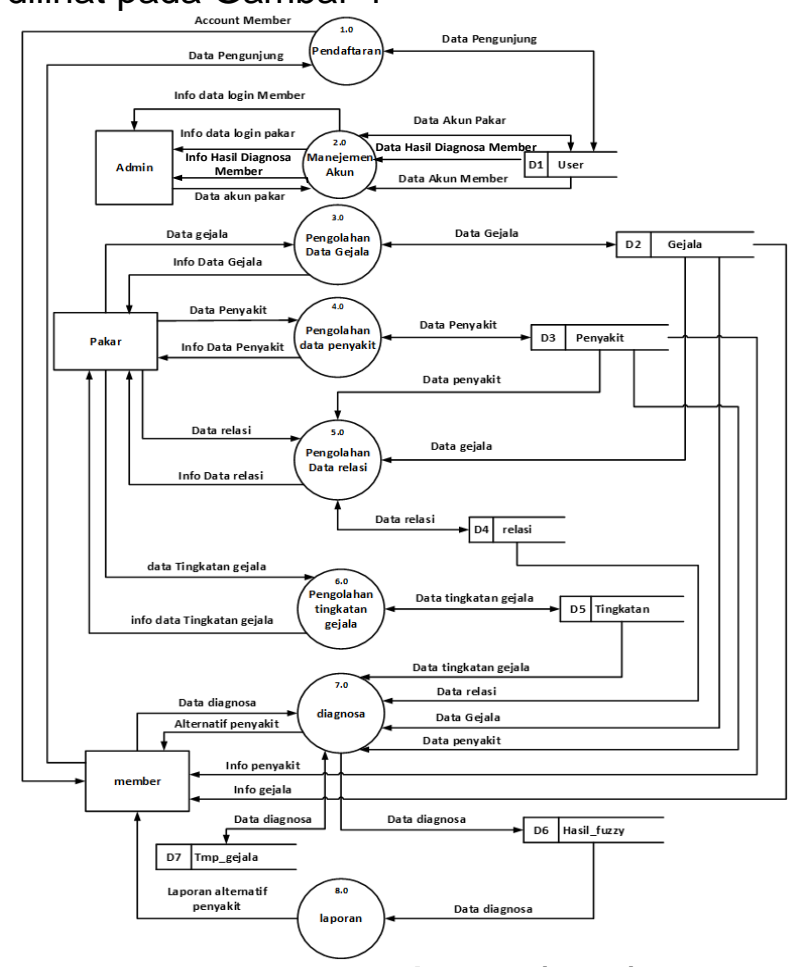

Gambar 4 Data Flow Diagram (DFD) Level 0 Sistem Pakar

\subsection{Implementasi Program}

\section{1) Halaman Web Login Member}

Halaman ini digunakan untuk masuk ke halaman member, untuk menjadi member user harus mendaftar terlebih dahulu, untuk mendaftar dapat melalui link daftar. Pada halaman ini user diminta memasukkan username dan password pada saat mendaftar, lalu tekan tombol login apabila berhasil akan masuk tetapi apabila terdapat kesalahan pemasukkan atau kosong maka muncul peringatan. Halaman web ini dapat dilihat pada Gambar 5. 


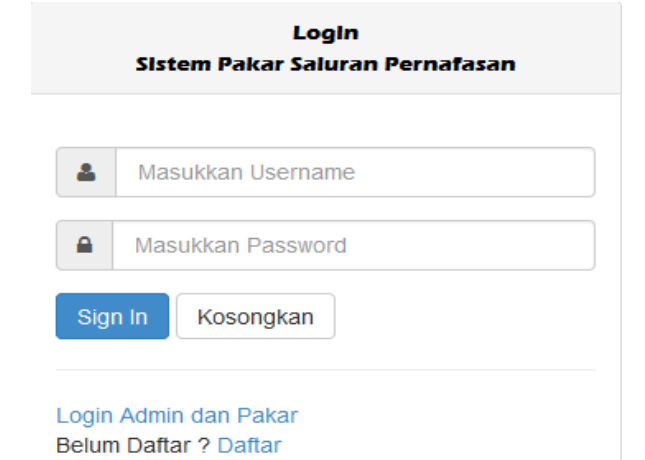

\section{Gambar 5 Halaman Web Login Member Sistem Pakar}

\section{2) Halaman Web Tampil Data Gejala}

Halaman ini digunakan untuk menampilkan data gejala, didalam halaman ini data gejala dapat ditambah, diubah, dan dihapus untuk menambah klik link tambah data gejala, untuk merubah klik edit pada tabel sedangkan untuk menghapus klik delete pada tabel. Halaman ini dapat dilihat pada gambar 6 .

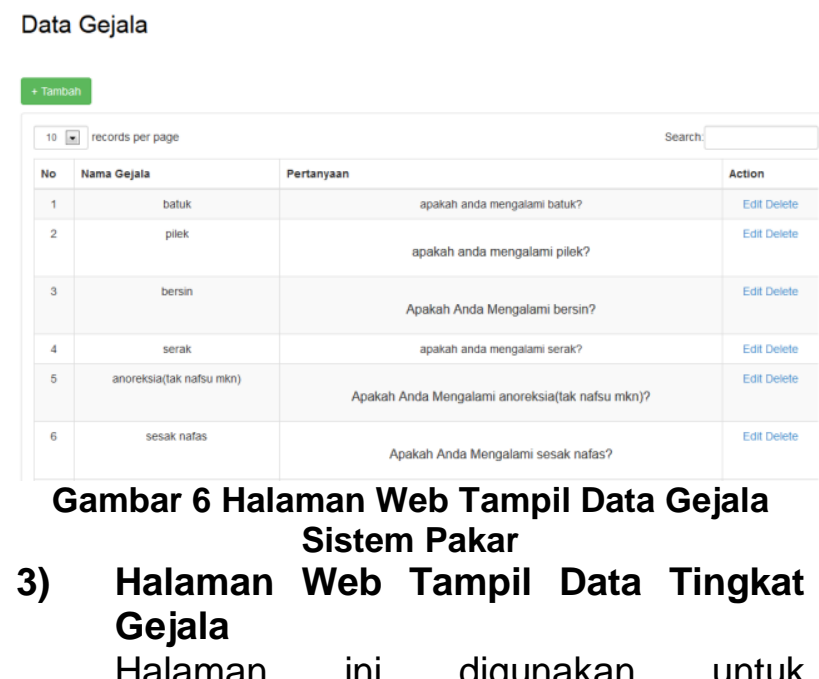
menampilkan data tingkatan gejala, didalam halaman ini data tingkatan gejala hanya dapat diubah untuk merubah klik logo edit pada tabel. Halaman ini dapat dilihat pada Gambar 7.

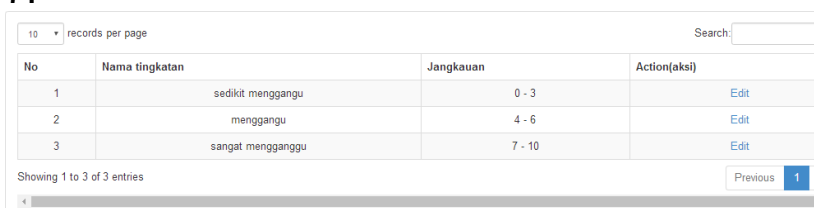

Gambar 7 Halaman Web Tampil Data Tingkat Gejala Sistem Pakar

\section{4) Halaman Web Tampil Data Relasi}

Halaman ini digunakan untuk menampilkan data relasi, didalam halaman ini data relasi dapat ditambah, diubah, dan dihapus untuk menambah klik link tambah data relasi, untuk merubah klik edit pada tabel sedangkan untuk menghapus klik delete pada tabel. Halaman ini dapat dilihat pada Gambar 8.

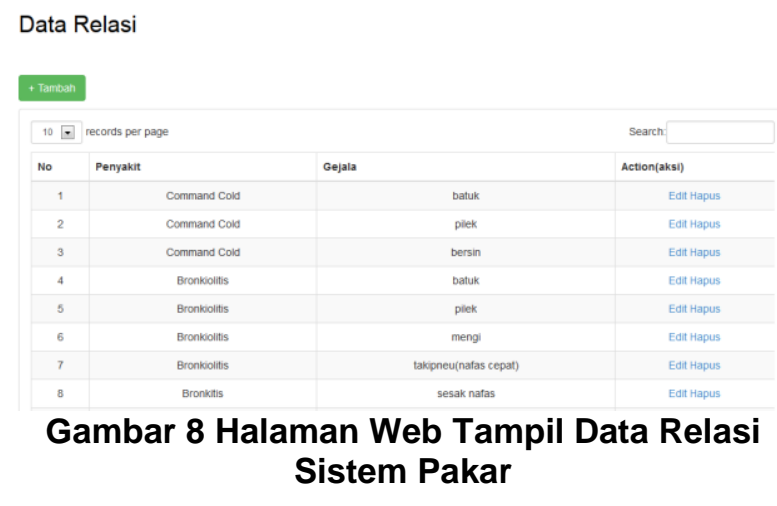

\section{5) Halaman Web Diagnosa Penyakit}

Halaman ini digunakan untuk memasukkan data seperti pertanyaan ya atau tidak bahwa member menderita gejala yang muncul di user interface dan apabila ya maka akan diminta untuk memasukkan tingkatan gejala antara 1-10 tetapi apabila tidak maka input tingkatan gejala akan nonaktif setelah itu klik tombol proses maka sistem akan memproses sampai penyakit ditemukan. Halaman ini dapat dilihat pada Gambar 9.

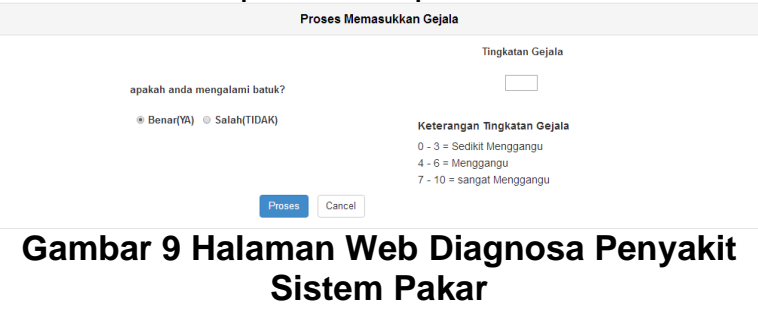

\subsection{Pengujian Validitas}

Pengujian validitas merupakan pengujian yang dilakukan untuk membandingkan apakah hasil antara perhitungan manual metode tsukamoto dengan perhitungan Tsukamoto pada sistem aplikasi sesuai atau tidak. Pada pengujian ini diberikan contoh masukkan seperti yang telah diujikan pada pengujian sistem yaitu sebagai berikut:

1. Mengalami gejala batuk dengan tingkat gejala $=2$

2. Mengalami gejala pilek dengan tingkat gejala $=2$

3. Mengalami gejala serak dengan tingkatan gejala $=4$

4. Mengalami gejala anoreksia (tidak nafsu makan) dengan tingkatan gejala $=7$

5. Mengalami gejala nyeri menelan Tingkatan Gejala $=5$

Hasil dari diagnosa dengan menggunakan penelusuran forward chaining dan perhitungan 
metode Tsukamoto yang dihasilkan oleh aplikasi seperti pada Gambar 10.

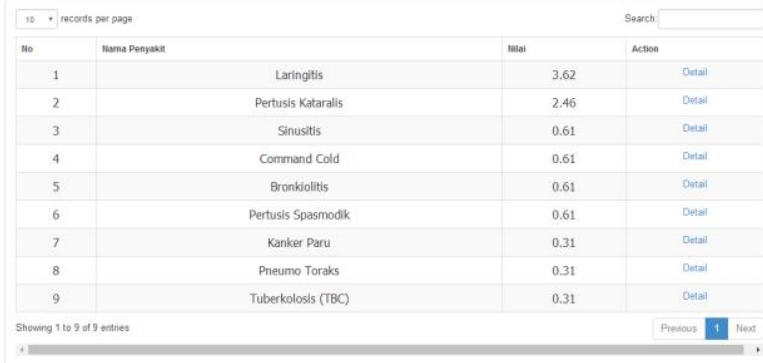

Penyakit Yang Kemungkinan Terbesar Diderita Pasien adalah Laringitis dengan Nilai 3.62

Gambar 10 Hasil Pengujian Sistem Pakar Proses Diagnosa Penyakit

\subsection{Pengujian perbandingan Antara Manual dan Sistem}

Setelah dilakukan pengujian dengan satu studi kasus antara hasil manual dengan sistem pakar saluran pernafasan didapat data seperti pada tabel 4 .

Tabel 4 Perbandingan Hasil Diagnosa Pakar dengan Sistem

\begin{tabular}{|c|c|c|c|c|c|c|}
\hline 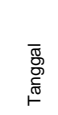 & 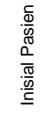 & 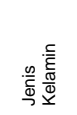 & $\frac{\frac{\pi}{\pi}}{\frac{\pi}{8}}$ & 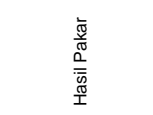 & 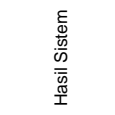 & 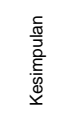 \\
\hline $\begin{array}{l}07-02- \\
2017\end{array}$ & NK & $\begin{array}{l}\text { Laki } \\
\text { dewasa }\end{array}$ & $\begin{array}{l}\text { Batuk, pilek, } \\
\text { nyeri kepala }\end{array}$ & Sinusitis & Sinusitis & Sesuai \\
\hline $\begin{array}{l}07-02- \\
2017\end{array}$ & NKA & $\begin{array}{l}\text { Wanita } \\
\text { dewasa }\end{array}$ & $\begin{array}{l}\text { Batuk, pilek, } \\
\text { mengi, sesak } \\
\text { nafas }\end{array}$ & Bronkiolitis & Bronkiolitis & Sesuai \\
\hline $\begin{array}{l}06-02- \\
2017\end{array}$ & FRE & $\begin{array}{l}\text { Wanita } \\
\text { anak }\end{array}$ & $\begin{array}{l}\text { Batuk, Pilek, } \\
\text { Serak, Susah } \\
\text { makan }\end{array}$ & Pertusis kataralis & $\begin{array}{l}\text { Pertusis } \\
\text { kataralis }\end{array}$ & Sesuai \\
\hline $\begin{array}{l}06-02- \\
2017\end{array}$ & $\mathrm{OA}$ & $\begin{array}{l}\text { Wanita } \\
\text { anak }\end{array}$ & Batuk, pilek & Command cold & Sinusitis & $\begin{array}{l}\text { Tidak } \\
\text { sesuai }\end{array}$ \\
\hline $\begin{array}{l}04-02- \\
2017\end{array}$ & MA & $\begin{array}{l}\text { Laki } \\
\text { anak }\end{array}$ & $\begin{array}{l}\text { Batuk, demam, } \\
\text { sesak nafas }\end{array}$ & Bronkitis & Tuberkolosis & $\begin{array}{l}\text { Tidak } \\
\text { sesuai }\end{array}$ \\
\hline $\begin{array}{l}03-02- \\
2017\end{array}$ & $\mathrm{ABR}$ & $\begin{array}{l}\text { Laki } \\
\text { anak }\end{array}$ & $\begin{array}{l}\text { Demam, pucat, } \\
\text { sesak nafas, } \\
\text { diare }\end{array}$ & Bronkopneumonia & $\begin{array}{l}\text { Bronkopneu } \\
\text { monia }\end{array}$ & Sesuai \\
\hline $\begin{array}{l}02-02- \\
2017\end{array}$ & $\mathrm{~N}$ & $\begin{array}{l}\text { Wanita } \\
\text { dewasa }\end{array}$ & $\begin{array}{l}\text { Batuk, pilek, } \\
\text { mengi }\end{array}$ & $\begin{array}{l}\text { Bronkiolitis } \\
\end{array}$ & $\begin{array}{l}\text { Pertusis } \\
\text { Spasmodik }\end{array}$ & $\begin{array}{l}\text { Tidak } \\
\text { Sesuai }\end{array}$ \\
\hline $\begin{array}{l}01-02- \\
2017\end{array}$ & $\mathrm{~s}$ & $\begin{array}{l}\text { Laki } \\
\text { dewasa }\end{array}$ & $\begin{array}{l}\text { Batuk, sesak } \\
\text { nafas, demam, } \\
\text { pucat }\end{array}$ & Pneumotoraks & $\begin{array}{l}\text { Pneumotorak } \\
\mathrm{s}\end{array}$ & Sesuai \\
\hline $\begin{array}{l}31-01- \\
2017\end{array}$ & MM & $\begin{array}{l}\text { Laki } \\
\text { dewasa }\end{array}$ & $\begin{array}{l}\text { Batuk, pilek, } \\
\text { bersin }\end{array}$ & Command cold & $\begin{array}{l}\text { Command } \\
\text { cold }\end{array}$ & Sesuai \\
\hline $\begin{array}{l}31-01- \\
2017\end{array}$ & $\mathrm{FC}$ & $\begin{array}{l}\text { Laki } \\
\text { dewasa }\end{array}$ & $\begin{array}{l}\text { Bersin, pilek, } \\
\text { batuk }\end{array}$ & Command cold & $\begin{array}{l}\text { Command } \\
\text { cold }\end{array}$ & Sesuai \\
\hline $\begin{array}{l}30-01- \\
2017\end{array}$ & $\mathrm{NA}$ & $\begin{array}{l}\text { Laki } \\
\text { anak }\end{array}$ & $\begin{array}{l}\text { Bersin, batuk, } \\
\text { pilek }\end{array}$ & Command cold & $\begin{array}{l}\text { Command } \\
\text { cold }\end{array}$ & Sesuai \\
\hline $\begin{array}{l}17-01- \\
2017\end{array}$ & $\mathrm{PA}$ & $\begin{array}{l}\text { Laki } \\
\text { dewasa }\end{array}$ & $\begin{array}{l}\text { Demam, batuk, } \\
\text { pilek, nyeri dada }\end{array}$ & Pneumonia & Pneumonia & Sesuai \\
\hline $\begin{array}{l}14-12- \\
2016\end{array}$ & A & $\begin{array}{l}\text { Laki } \\
\text { dewasa }\end{array}$ & Batuk, pilek & Command cold & $\begin{array}{l}\text { Command } \\
\text { cold }\end{array}$ & Sesuai \\
\hline $\begin{array}{l}13-12- \\
2016\end{array}$ & $\mathrm{LH}$ & $\begin{array}{l}\text { Laki } \\
\text { dewasa }\end{array}$ & $\begin{array}{l}\text { Batuk, pilek, } \\
\text { serak }\end{array}$ & Laringitis & Bronkiolitis & $\begin{array}{l}\text { Tidak } \\
\text { sesuai }\end{array}$ \\
\hline $\begin{array}{l}10-12- \\
2016\end{array}$ & FRA & $\begin{array}{l}\text { Laki } \\
\text { anak }\end{array}$ & $\begin{array}{l}\text { Batuk, pilek, } \\
\text { bersin }\end{array}$ & Command cold & $\begin{array}{l}\text { Command } \\
\text { cold }\end{array}$ & Sesuai \\
\hline $\begin{array}{l}03-12- \\
2016\end{array}$ & DTW & $\begin{array}{l}\text { Wanita } \\
\text { dewasa }\end{array}$ & $\begin{array}{l}\text { Batuk, } \\
\text { berdahak, serak }\end{array}$ & Command cold & $\begin{array}{l}\text { Command } \\
\text { cold }\end{array}$ & Sesuai \\
\hline $\begin{array}{l}30-11- \\
2016\end{array}$ & $\mathrm{CP}$ & $\begin{array}{l}\text { Wanita } \\
\text { dewasa }\end{array}$ & $\begin{array}{l}\text { Batuk, } \\
\text { berdahak, pilek, } \\
\text { bersin }\end{array}$ & Command cold & $\begin{array}{l}\text { Command } \\
\text { cold }\end{array}$ & Sesuai \\
\hline $\begin{array}{l}30-11- \\
2016\end{array}$ & SA & $\begin{array}{l}\text { Laki } \\
\text { anak }\end{array}$ & Batuk, pilek & Command cold & $\begin{array}{l}\text { Command } \\
\text { cold }\end{array}$ & Sesuai \\
\hline $\begin{array}{l}21-11- \\
2016\end{array}$ & AS & $\begin{array}{l}\text { Laki } \\
\text { anak }\end{array}$ & $\begin{array}{l}\text { Panas, batuk, } \\
\text { pilek }\end{array}$ & Command cold & $\begin{array}{l}\text { Command } \\
\text { cold }\end{array}$ & Sesuai \\
\hline $\begin{array}{l}17-11- \\
2016\end{array}$ & $\mathrm{KP}$ & $\begin{array}{l}\text { Laki } \\
\text { anak }\end{array}$ & $\begin{array}{l}\text { Batuk, sesak } \\
\text { nafas, demam, } \\
\text { mengi, pucat }\end{array}$ & Kanker Paru & Kanker Paru & Sesuai \\
\hline
\end{tabular}

Berdasarkan perbandingan pada Tabel 4 dapat diambil data bahwa Banyak data yang diuji $=20$ data Hasil Pengujian yang sesuai $=16$ data Hasil pengujian yang tidak sesuai $=4$ data Jadi nilai keakuratan adalah

$$
\frac{\text { Pengujian Sesuai }}{\text { Data yang diuji }} \times 100
$$

$$
\frac{16}{20} \times 100=80 \%
$$

\subsection{Skenario Pengujian Beta}

Adapun beberapa poin pertanyaan yang ditanyakan kepada koresponden meliputi:

a. Tampilan antar muka yang user friendly

b. Website dapat memenuhi kebutuhan informasi pelanggan.

c. Memudahkan pelanggan dalam melakukan diagnosa penyakit .

d. Website dapat mengatasi penyakit secara dini.

Berikut ini adalah hasil prosentase masing-masing jawaban. Kuesioner ini diujikan kepada 6 pasien dan 1 orang pakar dapat dilihat pada Tabel 5.

\begin{tabular}{|c|c|c|c|}
\hline Pertanyaan & Keterangan & Responden & $\begin{array}{c}\text { Prosentase } \\
(\%)\end{array}$ \\
\hline \multirow{4}{*}{1} & Sangat Baik & 2 & 28,57 \\
\hline & Baik & 5 & 71,42 \\
\hline & Kurang Baik & 0 & 0 \\
\hline & Sangat Kurang Baik & 0 & 0 \\
\hline \multirow{4}{*}{2} & Sangat Baik & 0 & 0 \\
\hline & Baik & 6 & 85,71 \\
\hline & Kurang Baik & 1 & 14,29 \\
\hline & Sangat Kurang Baik & 0 & 0 \\
\hline \multirow{4}{*}{3} & Sangat Baik & 3 & 42,86 \\
\hline & Baik & 4 & 57,14 \\
\hline & Kurang Baik & 0 & 0 \\
\hline & Sangat Kurang Baik & 0 & 0 \\
\hline \multirow{4}{*}{4} & Sangat Baik & 0 & 0 \\
\hline & Baik & 5 & 71,42 \\
\hline & Kurang Baik & 2 & 28.57 \\
\hline & Sangat Kurang Baik & 0 & 0 \\
\hline \multirow{4}{*}{5} & Sangat Baik & 3 & 42,86 \\
\hline & Baik & 4 & 57,14 \\
\hline & Kurang Baik & 0 & 0 \\
\hline & Sangat Kurang Baik & 0 & 0 \\
\hline
\end{tabular}

Tabel 5 Tabel Hasil Kuisioner

Berdasarkan tabel kesimpulan di atas bahwa untuk tampilan website memiliki prosentase terbesar yaitu 71,42 di keterangan baik, untuk user friendly/kemudahan sistem pakar saluran pernafasan mendapatkan prosentase terbesar yaitu 85,71 di keterangan baik, untuk membantu dalam proses informasi penyakit dan pengobatan/terapi mendapatkan prosentase terbesar yaitu 57,14 di keterangan baik, untuk membantu proses diagnosa menjadi lebih mudah mendapatkan prosentase terbesar yaitu 71,42 di keterangan 
baik, untuk sistem pakar ini memberikan informasi pengobatan penyakit saluran pernafasan secara akurat mendapatkan prosentase terbesar yaitu 57,14 di keterangan baik.

\section{PENUTUP}

\subsection{Kesimpulan}

Berdasarkan hasil pembahasan dan pengujian Sistem Pakar Diagnosa Penyakit Saluran Pernafasan yang telah dibuat dapat ditarik simpulan sebagai berikut :

a. Sistem Pakar Diagnosa Penyakit Saluran Pernafasan telah penulis buat dan dapat digunakan untuk membantu dalam memperkirakan penyakit yang diderita oleh pasien karena hasil sistem yang dikembangkan tidak jauh berbeda dengan sistem yang berjalan.

b. Berdasarkan hasil diagnosa penyakit pada sistem pakar dengan sistem manual maka tingkat keakuratan sistem adalah $80 \%$.

\subsection{Saran}

Berdasarkan pembuatan Sistem Pakar Diagnosa Penyakit Saluran Pernafasan dengan Metode Fuzzy Tsukamoto, maka untuk penelitian selanjutnya disarankan agar sistem ini dapat dikembangkan menjadi lebih baik, yaitu :
a. Dengan mengkolaborasikan metode fuzzy Tsukamoto dengan metode atau algoritma lain.
b. Menambahkan data penyakit yang tidak hanya berasal dari gejala fisik.

\section{DAFTAR PUSTAKA}

[1] D. Rubino and E. W. Puspitarini, "Gigi Dan Mulut Dengan Metode Forward Chaining Berbasis ( Studi Kasus Klinik Taruna Manggala Grup Surabaya )," J I M $P$ - J. Inform. Merdeka Pasuruan, vol. 1, no. 1, pp. 29-45, 2016.

[2] C. Pada, R. Yang, D. I. Jual, D. I. Sekitar, and K. Universitas, "Hubungan Penggunaan Apd Masker, Kebiasaan Merokok Dan Volume Kertas Bekas Dengan ISPA," Unnes J. Public Heal., vol. 2, no. 3, pp. 1-8, 2016.

[3] S. Kusumadewi, Aplikasi Logika Fuzzy. Yogyakarta: Graha Ilmu, 2010.

[4] K. Waluyo, Didik Nugroho, "Sistem Pakar Diagnosa Penyakit Dbd Dan Demam Tifoid Dengan Metode Fuzzy Tsukamoto," TIKomSiN, pp. 17-24, 2015.

[5] R. Ramlan, A. P. Cheng, S. W. Chan, and
Y. Ngadiman, "Implementation of Fuzzy Inference System for Production Planning Optimisation," 2016 Int. Conf. Ind. Eng. Oper. Manag., pp. 2151-2158, 2016.

[6] N. R. Sari and W. F. Mahmudy, "Fuzzy Inference System Tsukamoto Untuk Menentukan Kelayakan Calon Pegawai," Semin. Nas. Sist. Inf. Indones., no. November, pp. 2-3, 2015.

[7] O. Muhamad Muslihudin, Analisis dan Perancangan Sistem Informasi Menggunakan Model Terstruktur dan UML. Yogyakarta: Penerbit Andi, 2015. 